\title{
Physical, chemical and microbiological characteristics of stored greywater from unsewered urban Dakar, Senegal
}

\author{
O. Sall ${ }^{1} \&$ Y. Takahashi ${ }^{2}$ \\ ${ }^{1}$ Graduate School of Science and Technology, Niigata University, Japan \\ ${ }^{2}$ Faculty of Engineering, Niigata University, Japan
}

\begin{abstract}
Few studies have focused on the quality of greywater (GW) from urban developing countries. In the absence of urine and faeces, GW is generally considered as innocuous and as such, little attention is devoted to it. A physical, chemical and microbiological characterization of household GW from mixed sources was undertaken at Apecsy, in unsewered north suburban Dakar, with the aim of measuring the extent of health hazards related to the hand carrying system of GW. Samples were collected each two hours from a holding tank over 24 hours and analyzed for temperature, $\mathrm{pH}, \mathrm{EC}, \mathrm{DO}, \mathrm{FC}$ and $E$ coli, $\mathrm{BOD}_{5}, \mathrm{COD}$, TOC, TS, SS, VTS, TN, $\mathrm{NH}_{4}-\mathrm{N}, \mathrm{NO}_{3}-\mathrm{N}, \mathrm{TP}$ and $\mathrm{PO}_{4}-\mathrm{P}$. Results were then compared with raw combined domestic wastewater (CDW) and GW data from Dakar and developed countries. FC and E coli were lower in Apecsy GW compared to CDW from Dakar but varied in the same range as in typical raw CDW from the USA. GW was 5 times higher in organic matter and 3 times higher in solids than CDW. The chemical characteristics of organic matter and solids and the size distribution thereof in GW and CDW were similar. The organic matter in $\mathrm{GW}$ was found to be roughly biodegradable in spite of a severe nutrient deficiency noted. GW was of lower nitrogen and phosphorus. The higher GW strength was attributed to the combined effects of low flow and the storage of effluents, which are dependent on the hand-carrying system. The GW from unsewered urban developing countries may be more polluted than ordinary domestic wastewaters and as such, a change of attitude towards it is needed.

Keywords: physical chemical microbiological characteristics, stored greywater, combined domestic wastewater, unsewered areas, developing countries.
\end{abstract}




\section{Introduction}

The adequate treatment and disposal of domestic wastewaters in urban developing countries constitute a big and continual challenge for public authorities and local governments. In Senegal, the problem emanates both from a lack of funds to invest, an overwhelming population growth together with an unprecedented urbanization trend, and a lack of effective management and sufficient city planning. The concentration of economic activities, political institutions, urban facilities and opportunities in the capital-city of Dakar, to the detriment of other regions, has led to a fragmented development of the country, giving rise to growing social and territorial inequalities. This has resulted in massive rural to urban migrations towards Dakar, which accommodates $25 \%$ of the population of Senegal and $54 \%$ of urban dwellers on only $0.28 \%$ of the land, DPS [1]. The increasingly cramped conditions in Dakar have created an unprecedented pressure on the level of existing infrastructures and urban services, leading to a social and spatial segregation-based sanitation policy. The sewerage system of Dakar serves less than $20 \%$ of the population and is only limited to the city centre and surrounding high-income settlements. In suburban areas poorly designed on-site sanitation is used as a major sewage disposal option while the GW (wastewaters from kitchen, washing-up, laundry, infants' bathing and other small activities) is commonly discharged in streets at ground level. Since urine and faeces are not included, GW is generally viewed as a benign material, which poses a minor threat to humans and the environment. This unwarranted perception of GW and the careless handling of it may come from the lack of reliable information on the nature of $\mathrm{GW}$, since published data were not found in the literature for Senegal. At present, most of the available information on the quality of GW has been reported from developed countries where lifestyles, customs, climatic conditions and especially, water availability and usage habits are quite different to those in many developing countries. Moreover, most of this information focuses on source-separated effluent. Hence, improved knowledge on the nature of GW would be extremely valuable for evaluating the extent of health hazards associated with the hand-carrying system and also for reinforcing community awareness and promoting better sanitation practices.

\section{Materials and methods}

\subsection{Investigated areas}

The analysis presented in this paper uses data from two separate samplings. The first GW sampling was carried out in the residential housing of Apecsy situated in north suburban Dakar, about $20 \mathrm{~km}$ from the city centre, during January 23 24, 2005. The area consists of 34 families with a population of 304 inhabitants and covers a surface area of 1.6 ha. The average water consumption level estimated from the average of the last two water bills of each household was 47.5 1/capita/day. Household wastewaters are treated in two different ways. 
Blackwater and bathing water are collected and treated in a septic tank or latrines. GW is gradually collected and stored in buckets or pans and then handcarried to a GW holding tank or sometimes applied at ground level in streets.

Another GW sampling campaign was previously undertaken in a residential housing of 170 houses with 323 inhabitants located in Uchino, southwest suburban Niigata, Japan. Samples were collected from an open channel and analysed for the sake of comparison.

The CDW sampling took place in the city centre of Dakar during January 23 24, 2005. The investigated area included about 15,000 households with a population estimated at 138,000 inhabitants, given an average occupancy of 9.2, SDE [2]. The average water consumption level was 105 l/ capita/day. A sewer system collects raw CDW composed of both black waters (urine and faeces) and GW, of which only $10 \%$ is treated by Activated Sludge System. The remaining is dumped untreated into the sea. CDW samples were collected at the outlet of the University of Dakar.

\subsection{Sampling and analyses}

The same sampling method was applied to all sites. Two separate sets of samples were collected at each time of collection, one for the determination of the DO and the $\mathrm{BOD}_{5}$ and another for other parameters. For non conservable parameters (temperature, $\mathrm{pH}, \mathrm{EC}$ ) and the water flow, measurements were made on-site. Approximately $500 \mathrm{ml}$ samples were taken in labelled disposable plastic sampling bags at two hours interval, over a period of 24 hours. Samples were then kept in an icebox below $4^{\circ} \mathrm{C}$ during transportation and rapidly analyzed.

Analyses were performed following the "Standard Method for the Examination of Water and Wastewater [3] or the Japanese Industrial Standard, (JIS) [4], when appropriate. Measurements were carried out on ambient and water temperature (Glass thermometer, $0-100^{\circ} \mathrm{C}$ ), electrical conductivity (EC) (HORIBA conductivity meter B-173), pH (HORIBA Compact pH-meter D-13), dissolved oxygen (DO) (Winkler's titration), faecal coliforms (FC) (pour plate method, plate count agar, $15 \mathrm{~h}, 37^{\circ} \mathrm{C}$ ), E coli (pour plate method, desoxycholate agar, $15 \mathrm{~h}, 37^{\circ} \mathrm{C}$ ), $\mathrm{BOD}_{5}$ (Five-days BOD test, using unseeded dilution water, Standard Method 5210 B), COD (Open Reflux Method, Standard Method 5210 B), TOC (High Temperature Combustion Method, Standard Method 5310 B), total nitrogen (TN) (Colorimetric Method, JIS), ammonium $\left(\mathrm{NH}_{4}-\mathrm{N}\right)$ (Colorimetric Automated Phenate Method, Standard Method 4500- $\mathrm{NH}_{4}-\mathrm{F}$ ), nitrate $\left(\mathrm{NO}_{3}-\mathrm{N}\right)$ (Ultraviolet Colorimetric Screening Method, Standard Method $4500-\mathrm{NO}_{3}$-B), total phosphorus (TP) (Colorimetric method, measurement without filtration (JIS, 1997), orthophosphates $\left(\mathrm{PO}_{4}-\mathrm{P}\right)$ (Colorimetric Method, measurement after filtration through a 0.45 micron filter paper, JIS), total solids (TS), suspended solids (SS) and volatile total solids (VTS) (Standard Method 2540 D-Solids). 


\section{Results and discussions}

Results of water analyses are summarized in Table 1 and the behaviour of each water quality parameter is discussed in the following.

\subsection{Basic parameters}

The average volume of GW discharged by residents of Apecsy (6 L/capita/day) was found to be very low, compared to the $60 \mathrm{~L} /$ capita/day discharge in sewered areas of Dakar. This might be explained by the fact that bathing waters are not included in the GW and also by the absence or the lesser use of household facilities such as kitchen sinks, washing machines, bathtubs and basins by residents of Apecsy. Households are generally served by one plumbing fixture within the house and the water is hand-carried to different places of use. It was also suspected that a share of the daily produced GW was reused.

The GW and CDW flows varied differently during the day, fig. 1. The concentration of GW discharges from 10:00 to 17:00 contrasts with the more erratic curve of CDW flow. The reason lies in the difference of discharge conditions. The GW produced in the morning when high household activities take place, was stored and discharged at one time, usually before or after lunch in order to avoid going back and forth between the house and the point of discharge. Effluents produced in the evening were stored until the morning of the next day or sometimes discharged on the ground.

(a)

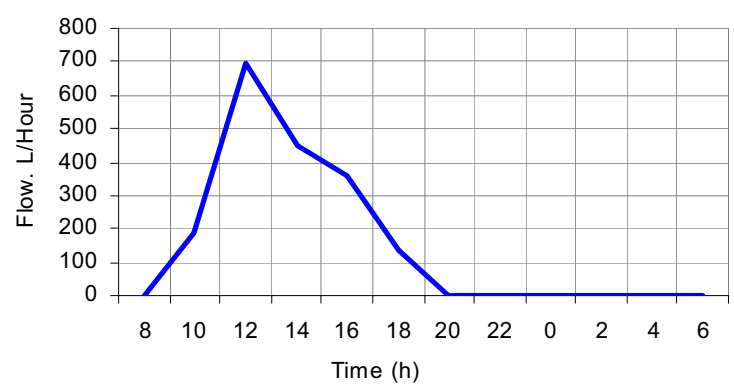

(b)

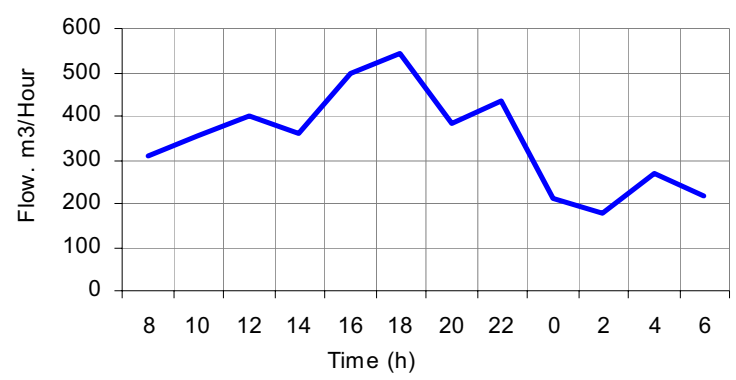

Figure 1: $\quad$ Daily variation of GW (a) and CDW (b) flow. 
The temperature of $\mathrm{GW}$ varied from 24.0 to $28.5^{\circ} \mathrm{C}$, with an average of $25.8^{\circ} \mathrm{C}$ and was close to values obtained for $\mathrm{CDW}$ from Dakar, which ranged from 23.0 to $28.0^{\circ} \mathrm{C}$. These temperature values were situated in the suitable range for bacterial activities and chemical reactions in wastewater $\left(25-35^{\circ} \mathrm{C}\right)$, Metcalf and Eddy [5]. The daily variations of GW temperature were similar to that of CDW.

The $\mathrm{pH}$ of $\mathrm{GW}$ was found to be slightly acidic in the range 6.4-7.0. These values are comparable to those of $\mathrm{CDW}$, situated in almost the same range: 6.7-7.1. The low $\mathrm{pH}$ values should be attributed to the presence of large amounts of food particles containing acid and particularly the presence of cooking oil, largely consumed in Senegal. The daily variation of $\mathrm{pH}$ in $\mathrm{GW}$ showed fewer fluctuations, fig 2. Comparison with standard literature values indicates $\mathrm{pH}$ levels for stored GW in similar range 6.7-7.6 [6] and 5-7, Rose et al. [7].

The EC of GW varied from 1.4 to $2.9 \mathrm{mS} / \mathrm{cm}$ with an average value of $2.4 \mathrm{mS} / \mathrm{cm}$. It was almost constant during the day but decreased slightly during the night, fig. 2. In contrast, the EC of CDW fluctuated from 1.0 to $4.1 \mathrm{~ms} / \mathrm{cm}$ with two peaks at 04:00 and 16:00, respectively. This is thought to originate from illegal intrusions of high EC industrial wastewaters into the sewer system.

\subsection{Micro-organisms}

In the absence of urine and faeces the faecal contamination level in the GW is expected to be minimal, Ottoson et al. [8]. But in this study, FC and especially $E$ coli were found to be significantly high in GW: in the range $2.2 \times 10^{5}-3.7 \times 10^{5}$ $\mathrm{cfu} / 100 \mathrm{ml}$ and $1.5 \times 10^{4}-4.9 \times 10^{4} \mathrm{cfu} / 100 \mathrm{ml}$, respectively. For comparison, FC and $E$ coli were higher in CDW from Dakar: in the range $3.1 \times 10^{7}-2.1 \times 10^{8} \mathrm{cfu} / 100 \mathrm{ml}$ and $4.1 \times 10^{6}-1.5 \times 10^{7} \mathrm{cfu} / 100 \mathrm{ml}$, respectively, but varied in lower range in $\mathrm{GW}$ from Uchino, Japan, Table 1. Reported data from the USA [5] have shown FC density in typical untreated domestic wastewater in the order of $10^{4}-10^{5} \mathrm{cfu} / 100 \mathrm{ml}$. This indicates that FC in GW from Apecsy was in the same range reported for typical untreated CDW from developed countries.

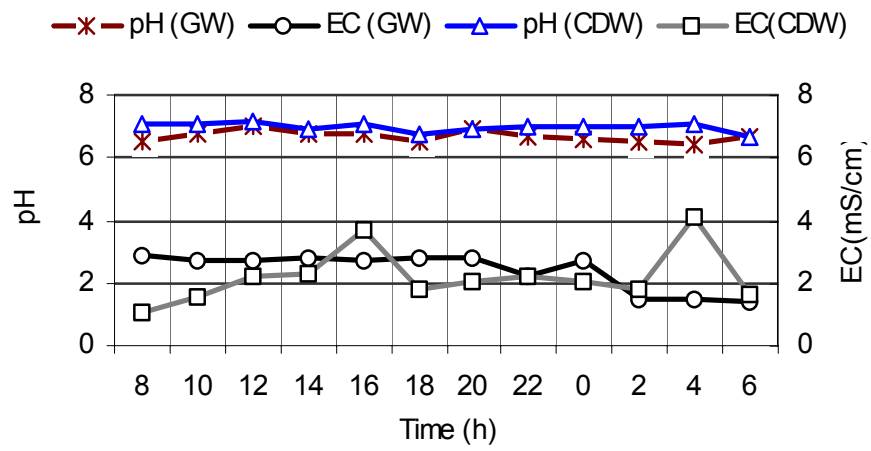

Figure 2: Daily variation for $\mathrm{pH}$ and $\mathrm{EC}$ in $\mathrm{GW}$ and $\mathrm{CDW}$ from Dakar. 
632 Water Pollution VIII: Modelling, Monitoring and Management

\begin{tabular}{|c|c|c|c|c|c|c|c|c|c|c|c|c|c|c|c|c|c|c|}
\hline 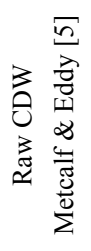 & $\mid \begin{array}{l}\stackrel{8}{\infty} \\
\stackrel{\Xi}{\approx} \\
\approx\end{array}$ & & & & $\begin{array}{l}\infty \\
0 \\
1 \\
\dot{0} \\
0\end{array}$ & $\left|\begin{array}{c}3 \\
0 \\
1 \\
0 \\
0\end{array}\right|$ & & $\begin{array}{l}8 \\
⿱ 亠 䒑 十 \\
1 \\
\varrho\end{array}$ & $\begin{array}{c}8 \\
8 \\
-1 \\
1 \\
\stackrel{5}{i}\end{array}$ & $\begin{array}{l}8 \\
2 \\
1 \\
\infty\end{array}$ & $\mid \begin{array}{l}n \\
\infty \\
1 \\
\tilde{N}\end{array}$ & $\begin{array}{l}i \\
i \\
1 \\
\simeq\end{array}$ & 0 & $\begin{array}{l}n \\
\dot{q} \\
\dot{f}\end{array}$ & & 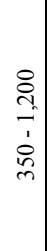 & $\mid \begin{array}{c}0 \\
0 \\
1 \\
1 \\
8 \\
-1\end{array}$ & 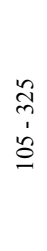 \\
\hline $\begin{array}{ll}3 & a \\
0 & 0 \\
0 & 0 \\
0 & 0 \\
0 & 0 \\
0 & 0 \\
\infty & 0\end{array}$ & 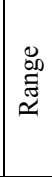 & & & $\begin{array}{l}r \\
\infty \\
1 \\
b \\
0\end{array}$ & 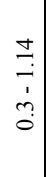 & & & $\begin{array}{l}8 \\
\grave{1} \\
\dot{2}\end{array}$ & & & $\begin{array}{l}\tilde{n} \\
\dot{n}\end{array}$ & $\begin{array}{c}a \\
\mathfrak{v} \\
\dot{\vec{\theta}} \\
\dot{\vec{v}}\end{array}$ & $\left|\begin{array}{c}\infty \\
0 \\
1 \\
\dot{0} \\
\dot{v}\end{array}\right|$ & $\begin{array}{l}\widehat{N} \\
1 \\
0 \\
0\end{array}$ & & & $\begin{array}{c}0 \\
\tilde{m} \\
\stackrel{1}{1} \\
\dot{y}\end{array}$ & \\
\hline 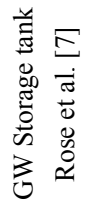 & $\mid \begin{array}{l}\text { 品 } \\
\text { Е } \\
\approx\end{array}$ & & & $\begin{array}{l}0 \\
i \\
\vdots \\
i \\
\text { in }\end{array}$ & & & & & & & $\mid \begin{array}{c}n \\
n \\
1 \\
b \\
0 \\
0\end{array}$ & $\begin{array}{c}n \\
n \\
1 \\
n \\
0 \\
0\end{array}$ & $\begin{array}{l}\stackrel{g}{+} \\
\dot{0}\end{array}$ & & $\begin{array}{c}n \\
m \\
1 \\
\dot{r}\end{array}$ & & & \\
\hline 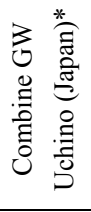 & 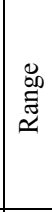 & 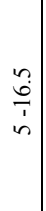 & 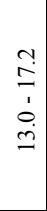 & \begin{tabular}{l}
$\infty$ \\
0 \\
$i$ \\
1 \\
\multirow{2}{*}{} \\
$i$
\end{tabular} & $\begin{array}{c}0 \\
\dot{r} \\
\dot{I} \\
\dot{I}\end{array}$ & 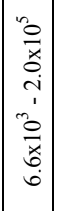 & 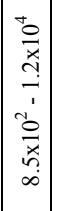 & $\begin{array}{l}a \\
\dot{0} \\
\dot{n} \\
\dot{b} \\
\dot{m}\end{array}$ & 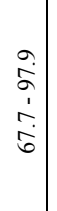 & $\mid \begin{array}{l}0 \\
\tilde{1} \\
0 \\
n\end{array}$ & $\mid \begin{array}{c}\dot{0} \\
\dot{b} \\
\dot{1} \\
\vec{i}\end{array}$ & $\begin{array}{c}\dot{J} \\
\dot{\vec{v}} \\
\dot{1} \\
\infty \\
\dot{m} \\
\dot{m}\end{array}$ & $\begin{array}{l}\stackrel{+}{\rightarrow} \\
\stackrel{\leftrightarrow}{\rightarrow} \\
\rightarrow\end{array}$ & 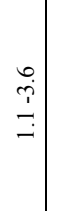 & $\begin{array}{l}0 \\
0 \\
0 \\
1 \\
0\end{array}$ & 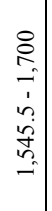 & 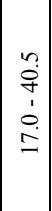 & 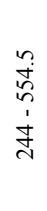 \\
\hline 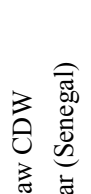 & 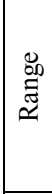 & 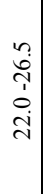 & $\begin{array}{l}0 \\
\dot{d} \\
i \\
\vdots \\
\dot{i}\end{array}$ & $\begin{array}{l}\frac{1}{3} \\
\frac{1}{6}\end{array}$ & 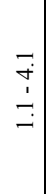 & 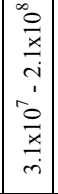 & 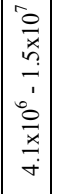 & 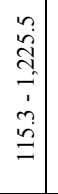 & 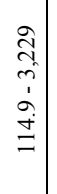 & $\mid \begin{array}{l}n \\
\infty \\
\infty \\
\infty \\
\infty \\
1 \\
n \\
\tilde{n}\end{array}$ & 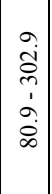 & $\begin{array}{l}0 \\
\dot{d} \\
\stackrel{1}{0} \\
\dot{+}\end{array}$ & $\left|\begin{array}{l}n \\
n \\
1 \\
n \\
n\end{array}\right|$ & 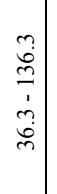 & $\begin{array}{l}\stackrel{+}{+} \\
\dot{+} \\
1 \\
\infty \\
\dot{\Xi} \\
=\end{array}$ & $\begin{array}{l}\infty \\
\stackrel{0}{1} \\
\dot{1} \\
\vec{J}\end{array}$ & 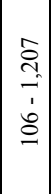 & 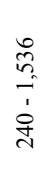 \\
\hline$\simeq$ 气ै & 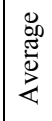 & $\begin{array}{l}0 \\
\vec{\lambda}\end{array}$ & $\begin{array}{c}\dot{d} \\
\dot{a}\end{array}$ & $\stackrel{\circ}{\stackrel{2}{2}}$ & $\stackrel{\sim}{i}$ & 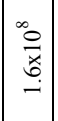 & 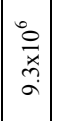 & $\begin{array}{l}\hat{a} \\
\hat{0} \\
\dot{0}\end{array}$ & $\begin{array}{l}\stackrel{0}{7} \\
\stackrel{-}{-}\end{array}$ & $\mid \begin{array}{l}m \\
o \\
q\end{array}$ & 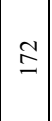 & $\begin{array}{l}\infty \\
\infty \\
\infty\end{array}$ & $\vec{i}$ & m. & $\begin{array}{l}0 \\
\text { in }\end{array}$ & 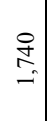 & ठેे & $\vec{\infty}$ \\
\hline 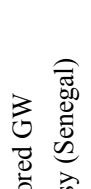 & 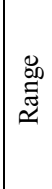 & $\begin{array}{l}m \\
\stackrel{D}{0} \\
\dot{1} \\
\stackrel{i}{i}\end{array}$ & $\begin{array}{l}n \\
\infty \\
i \\
1 \\
0 \\
\dot{d}\end{array}$ & 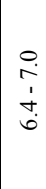 & $\begin{array}{l}\vec{i} \\
i \\
\dot{J} \\
\dot{H}\end{array}$ & 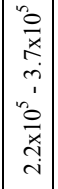 & 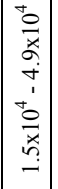 & $\begin{array}{c}n \\
i \\
0 \\
0 \\
0 \\
1 \\
\infty \\
0 \\
0 \\
0 \\
i \\
i\end{array}$ & $\begin{array}{l}\hat{i} \\
\dot{0} \\
0 \\
\vec{i} \\
1 \\
\tilde{n} \\
0 \\
\tilde{n}\end{array}$ & $\begin{array}{c}n \\
0 \\
0 \\
0 \\
1 \\
\infty \\
\infty\end{array}$ & $\mid \begin{array}{c}0 \\
\dot{n} \\
n \\
n \\
1 \\
\vdots \\
\dot{n}\end{array}$ & $\begin{array}{c}\infty \\
\dot{\sim} \\
\dot{1} \\
\vdots \\
\dot{a} \\
-\end{array}$ & $\begin{array}{c}m \\
\stackrel{n}{2} \\
\dot{\infty} \\
\stackrel{n}{n}\end{array}$ & $\begin{array}{l}n \\
\tilde{b} \\
1 \\
0 \\
\dot{9}\end{array}$ & $\begin{array}{l}n \\
0 \\
0 \\
1 \\
=\end{array}$ & 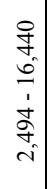 & $\left|\begin{array}{c}8 \\
8 \\
\text { n. } \\
1 \\
1 \\
n \\
n\end{array}\right|$ & 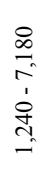 \\
\hline 冓 & 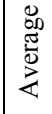 & $\stackrel{\leftrightarrow}{\dot{d}}$ & $\begin{array}{l}\infty \\
\dot{a}\end{array}$ & $\hat{\sigma}$ & $\stackrel{+}{i}$ & $\left|\begin{array}{c}n \\
0 \\
\bar{x} \\
\infty \\
i\end{array}\right|$ & 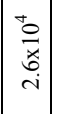 & $\begin{array}{l}n \\
\infty \\
\infty \\
\infty \\
2 \\
+\end{array}$ & $\begin{array}{l}2 \\
\vdots \\
\dot{v} \\
\vdots \\
\infty\end{array}$ & 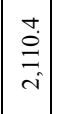 & 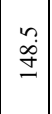 & $\stackrel{\text { ì }}{\mathrm{i}}$ & $\begin{array}{l}\stackrel{0}{\mathrm{I}} \\
\stackrel{\mathrm{J}}{ }\end{array}$ & $\ddot{8}$ & $\ddot{6}$ & $\frac{g}{d}$ & $\mid \begin{array}{l}\mathscr{O} \\
\stackrel{2}{-}\end{array}$ & $\stackrel{\infty}{\stackrel{\infty}{0}}$ \\
\hline & 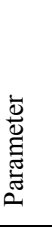 & 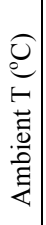 & $\begin{array}{l}0 \\
0 \\
0 \\
5 \\
\overline{0} \\
\tilde{0} \\
3\end{array}$ & 胥 & 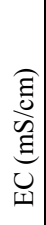 & 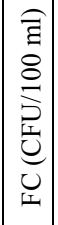 & 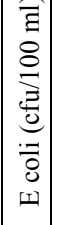 & 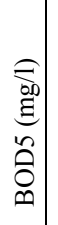 & 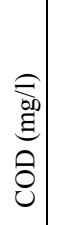 & 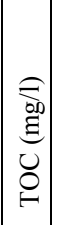 & 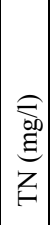 & 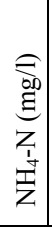 & $\mid \begin{array}{c}\sigma 0 \\
00 \\
\Xi \\
z \\
1 \\
0 \\
z\end{array}$ & 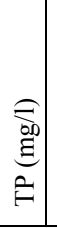 & 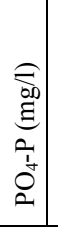 & 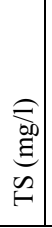 & 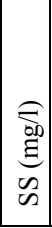 & $\begin{array}{l}\widehat{\sigma} \\
5 \\
\Xi \\
0 \\
5 \\
5\end{array}$ \\
\hline
\end{tabular}


Bacteria are suspected to enter the GW from washing of infants' faecally contaminated clothes and from children's bathing water itself, and to a lesser extent from food preparation. Casanova et al. [10] found that the density of FC in GW of a household of two adults and one child was higher than that in effluents generated from a household of only two adults.

Uncooked vegetable and raw meat are also potential sources of contamination of GW, Eriksson et al. [11]. The high bacteria level in Apecsy GW could be attributed to the storage of effluents that allows rapid bacterial growth favoured by high concentrations of degradable organic matter in GW. Such a growth has been reported for FC and E coli in GW during storage [8].

The health implications of the high bacterial concentration in GW are closely dependent on the hand-carrying system, which constitutes a serious exposure route to bacterial contamination as it allows human contact with the effluents on a daily basis.

\subsection{Oxygen consuming compounds}

Results have revealed five times higher levels of organic matters in GW from Apecsy than in CDW from Dakar, fig. 3. The average COD, BOD 5 , and TOC for GW have been measured at 8.5, 4.4, and $2.1 \mathrm{~g} / 1$, compared to $1.3,0.7$, and $0.4 \mathrm{~g} / 1$ for CDW. The DO in GW was completely depleted, as expected considering the high concentration of organics.

The higher level of organic matter in GW was attributed to the combined effect of much lower flow and the presence of large amounts of food particles as important source of proteins from kitchen wastewater. The higher COD of GW could derive from the effect of low GW flow and the use of household chemicals like dishwashing and laundry detergents [11].

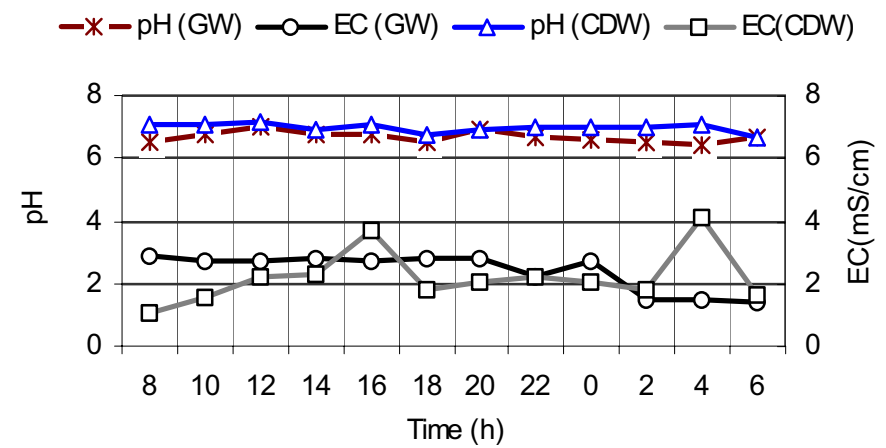

Figure 3: Daily variation for concentration of organic pollutants in GW (a) and CDW (b).

For comparison, the $\mathrm{COD}, \mathrm{BOD}_{5}$ and $\mathrm{TOC}$ of $\mathrm{GW}$ generated from the residential area of Uchino were found to vary in much lower ranges of 67.7-97.9 mg/1, 31.0-40.0 mg/1 and 30.0-36.0 mg/l, respectively, Table 1 . The 
lower concentration of organic matter in GW of Uchino is due to the much higher per capita water consumption of Japanese householders, which varies in average between 300-400 1/day, Herath [12]. Reported data from Australia have shown a $\mathrm{BOD}_{5}$ concentration in septic tank storage $\mathrm{GW}$ in the order of 90-290 $\mathrm{mg} / \mathrm{l}[9]$.

The COD, $\mathrm{BOD}_{5}$ and TOC concentrations in $\mathrm{GW}$ varied in an almost similar pattern. As for CDW from Dakar more erratic patterns were obtained than for organic concentration in $\mathrm{GW}$, fig 3 .

\subsection{Solids}

The concentration of solids in the GW was found to be three times higher than that measured in the CDW. The TS, SS and VTS in the GW ranged from 2.5 to $16.5 \mathrm{~g} / 1,0.5$ to $6.3 \mathrm{~g} / 1$ and 1.2 to $7.1 \mathrm{~g} / 1$, compared to $0.7-3.1 \mathrm{~g} / 1,0.1-1.2 \mathrm{~g} / 1$ and 0.2-1.5 g/1, for CDW, respectively, fig. 4 .

(a)

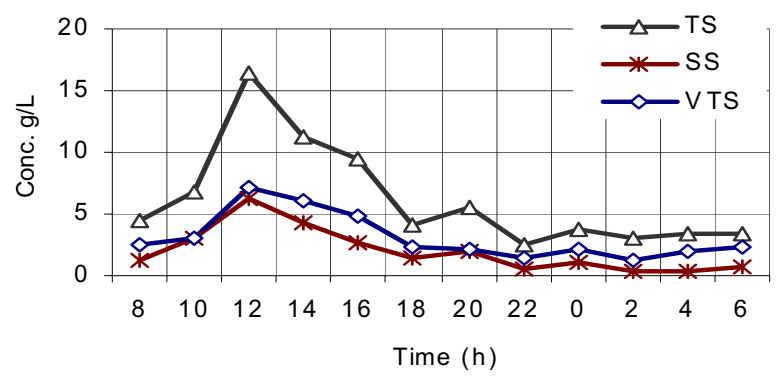

(b)

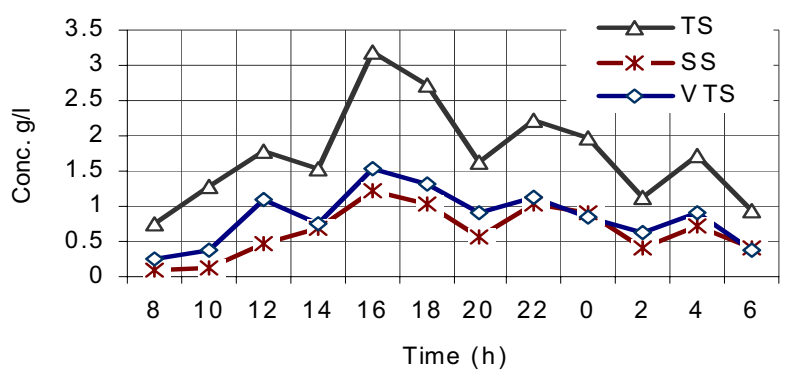

Figure 4: Daily variation for concentration of solids in GW (a) and CDW (b) from Dakar.

This result does not comply with reported data stating that GW is relatively low in SS and turbidity compared to domestic wastewater Jefferson et al. [13], [11]. Comparison with standard literature values from some industrial countries revealed lower solids levels for septic tank storage GW [9] and for typical untreated CDW [5], Table 1. The higher solid strength of GW might come from the lower flow, the common practice of disposing of food leftovers with kitchen and washing-up wastewaters and the presence of fat and oils in effluents. The 
combination of colloids and surfactants from detergents may also result in a stabilization of solids by sorption of the surfactant on the colloid surface [11]. The use of sand for cleaning cooking utensils, which are usually smeared with a mixture of charcoal ash and water, to prevent them from blackening, may also increase the solids level in the GW. However, the chemical characteristics (organic/inorganic fraction) and the size distribution of solids in GW and CDW were found to be quite similar.

The organic fraction (VTS), accounted for 50\% of TS in GW and $48.4 \%$ in CDW. Similarly, the SS contributed for $32 \%$ of TS in GW and $36 \%$ in CDW. The relatively low value of SS complies with reported data elsewhere indicating that the greater proportion of contaminants in GW is dissolved [13].

The variation of solids in GW and CDW showed different patterns, and seemed correlated to the flow, fig. 4.

a)
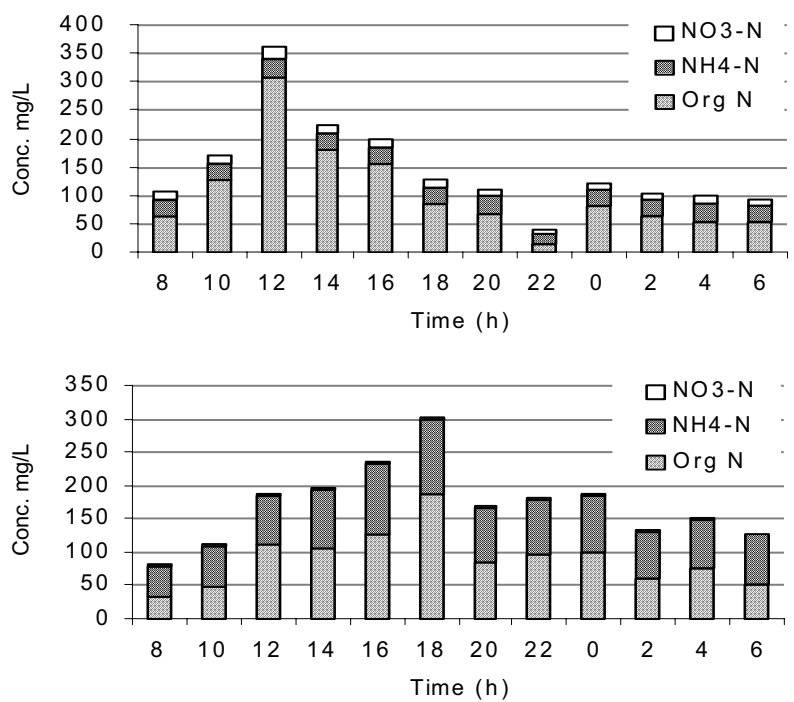

Figure 5: Daily variation for nitrogen compounds in GW (a) and CDW (b) from Dakar.

\subsection{Nitrogen}

The GW was of lower $\mathrm{TN}$ and $\mathrm{NH}_{4}-\mathrm{N}$ than $\mathrm{CDW}$ but the proportion of $\mathrm{NO}_{3}-\mathrm{N}$ to $\mathrm{TN}$ present was found to be higher, fig. 5. The average concentrations of TN and $\mathrm{NH}_{4}-\mathrm{N}$ were measured at 148.5 and $29 \mathrm{mg} / \mathrm{l}$ in $\mathrm{GW}$ compared to 171.6 and 78.8 $\mathrm{mg} / \mathrm{l}$ for $\mathrm{CDW}$, respectively. $\mathrm{NO}_{3}-\mathrm{N}$ concentrations were measured at $12.6 \mathrm{mg} / \mathrm{l}$ in GW and only $2.7 \mathrm{mg} / \mathrm{l}$ in CDW. The lower nitrogen content of GW should be explained by the absence of urine as an important nitrogen contributory source. However, the nitrogen level in GW remains high compared to GW and CDW from developed countries, probably due to the low GW flow, Table 1. Differences noted in the chemical natures of nitrogen compounds in GW and CDW are attributed to the differences in effluent discharge conditions between 
unsewered and sewered areas. The higher nitrate level in the GW probably resulted from the storage of effluents that allows the conditions for a complete oxidation of the organic nitrogen in the water since $\mathrm{NO}_{3}-\mathrm{N}$ is formed at a late stage of oxidation. On the other hand, the higher proportion of $\mathrm{NH}_{4}-\mathrm{N}$ to $\mathrm{TN}$ in CDW (46\% compared to $19.5 \%$ for GW) should be explained respectively by the continuous input of fresh effluents in the sewer system and the relatively shorter residence time of effluents in the sewer network.

The nitrogen content of GW and that of CDW varied differently during the day but seemed to respond to the variation of their respective flow, fig. 5 .

\subsection{Phosphorus}

The GW was of lower phosphorus concentration with an average TP and $\mathrm{PO}_{4}-\mathrm{P}$ level of 60 and $16.1 \mathrm{mg} / 1$ compared to 69.3 and $22.6 \mathrm{mg} / 1$ for CDW. The lower phosphorus level in GW is probably due to the absence of urine in GW but also to the lesser use of phosphorus containing detergents by residents of Apecsy. The lower level of phosphorus might also be due to the absence of bathing water as an important phosphorus contributory source. Phosphorus was found in both samples, mainly in the form of suspended phosphorus.

For comparison, the phosphorus level in Uchino GW varied between 1.1 and $3.6 \mathrm{mg} / \mathrm{l}$ for $\mathrm{TP}$ while $\mathrm{PO}_{4}-\mathrm{P}$ was barely detected. Comparison with standard literature data from industrial countries revealed concentration range of 0.6-27.3 mg/l for TP in septic GW [8], 4-35 mg/1 for $\mathrm{PO}_{4}-\mathrm{P}$ in tank storage GW [7], 4-15 mg/l and 3-10 mg/l for TP and $\mathrm{PO}_{4}-\mathrm{P}$ in typical raw CDW, respectively $[5]$.

\subsection{Biodegradability of GW}

The biodegradability of the organic matter in GW was evaluated from both the $\mathrm{COD}: \mathrm{BOD}_{5}$ ratio and the $\mathrm{BOD}_{5}: \mathrm{N}: \mathrm{P}$ weight ratio, which expresses the nutrient balance with the organic content in the wastewater. The average COD:BOD ratio of the GW was measured at 1.9:1 compared to 1.7:1 for CDW. The nutrient balance has been evaluated from the ratio of the BOD to the amount of inorganic nitrogen $\left(\mathrm{NH}_{4}-\mathrm{N}\right.$ and $\left.\mathrm{NO}_{3}-\mathrm{N}\right)$ and orthophosphate $\left(\mathrm{PO}_{4}-\mathrm{P}\right)$ readily available in the wastewater. The $\mathrm{BOD}_{5}:\left(\mathrm{NH}_{4}+\mathrm{NO}_{3}\right): \mathrm{PO}_{4}$ weight ratio in $\mathrm{GW}$ was measured at 4,388.5:0.9:0.4 compared to 668.9:11.3:3.4 for CDW. The required $\mathrm{BOD}_{5}: \mathrm{N}: \mathrm{P}$ ratio for an efficient aerobic $\mathrm{BOD}$ removal is 100:5:1. This indicates that the organic matter in both GW and $\mathrm{CDW}$ was roughly biodegradable but the severe nutrient deficiency observed in GW might be limiting in the biological degradation of the organic matter.

\section{Conclusion}

The study illustrated the need of basic and valuable information on the nature and discharge conditions of GW from urban developing countries. It has been shown that the GW generated from unsewered urban Dakar was physically more polluted than, and chemically and microbiologically as polluted as the raw 
CDW. The comparison of analyses results with literature data on GW and CDW from industrial countries revealed significantly higher concentrations of main pollution parameters in Apecsy GW. This implies that a change of attitude towards GW is necessary from both public authorities and populations themselves. Local discharge conditions were found to be determinant in GW quality changes. The hand-carrying system of the GW in unsewered areas represents a direct exposure route to bacterial contamination of residents, as it allows human contact with GW on a daily basis. The storage of GW at home should be avoided as it favours bacterial growth. Further GW characterisation would be valuable for promoting community awareness and for providing basic information that can be used in the context of sub-saharan African countries.

\section{References}

[1] DPS, Situation économique et sociale du Senegal. République du Sénégal. Ministère de l'économie et des finances. Direction de la Prévision et de la Statistique (DPS), pp. 197, 2003.

[2] DPS, Situation économique et sociale du Senegal. République du Sénégal. Ministère de l'économie et des finances. Direction de la Prévision et de la Statistique (DPS), pp. 197, 2003.

[3] APHA., Standard Methods for the Examination of Water and Wastewater. APHA. American Public Health Association, 20 Ed., pp. 1198, 1998.

[4] JIS., Japanese Industrial Standard for Sewage Examination. JIS, pp. 812, 1997.

[5] Metcalf \& Eddy., Wastewater Engineering: Treatment, Disposal and Reuse. $3^{\text {rd }}$ ed. Metcalf \& Eddy, Inc., pp. 1334, 1991.

[6] Dixon, A., Butler, D., Fewkes. A., Robinson. M., Measurement and modeling of quality changes in stored untreated grey water. Urban Water, 1, pp. 293 306, 1999.

[7] Rose. J. B., Sun. G., Gerba. C. P., Sinclair. N. A., Microbial quality and persistence of enteric pathogens in greywater from various household sources. Water Research, 25(1), pp. 37 42, 1991.

[8] Ottoson J., Stenstrom T. A., Faecal contamination of greywater and associated microbial risks. Water Research, 37, pp. 645 655, 2003.

[9] Jeppesen B., Domestic greywater reuse: preliminary evaluation. Urban water Research Association of Australia, Research report No 60., 1993.

[10] Casanova, L. M., Gerba. C. P., Karpiscak. M., Chemical and microbial characterization of household graywater. J. Environmental Science and Health, A 36 (4), pp. 395-401, 2001.

[11] Eriksson. E., Auffarth. K., Henze. M., Ledin. A., Characteristics of grey wastewater. Urban Water, 4, pp. 85 104, 2001.

[12] Herath, S., Safe water and international cooperation water problems in developing countries. Environment and Sustainable Development Program. United Nations University. http://www.unu.edu/hq/Japanese /gsj/gs2003j/hokkaido3/herath-ab-c.html-

[13] Jefferson, B. Laine. A., Parson. S., Stephensen T., Judd. S., Technologies for domestic wastewater recycling. Urban Water, 1, 285-292 pp., 1999. 